\title{
Dividend Policy and Bank Performance in Ghana
}

\author{
Samuel Kwaku Agyei (Corresponding author) \\ Department of Accounting and Finance, School of Business, University of Cape Coast, Cape Coast - Ghana
}

Tel: 233 27-765-5161 E-mail: twoices2003@yahoo.co.uk

Edward Marfo-Yiadom

Department of Accounting and Finance, School of Business, University of Cape Coast, Cape Coast - Ghana

Tel: 233-24-451-5162 E-mail: emyiadom@yahoo.com

Received: October 29, 2010

Accepted: January 24, 2011

doi:10.5539/ijef.v3n4p202

\begin{abstract}
The main thrust of this study is to find out the relationship between dividend policy and performance of banks in Ghana. The study used panel data constructed from the financial statements of 16 commercial banks in Ghana for a period of 5 years, from 1999-2003. These financial statements were obtained from the Banking Supervision department of Bank of Ghana. STATA was used for the data analysis. From the results of the study, the average dividend paid by banks over the study period was $24.65 \%$. Also, it is apparent that banks that pay dividend increase their performance. The results also reinforce earlier findings that leverage, size of a bank and bank growth enhance the performance of banks. The age factor presents mixed results. Generally, the result is in tandem with earlier studies that dividend policy has an effect on firm value.
\end{abstract}

Keywords: Dividend policy, Debt, Bank performance, Ghana

\section{Introduction}

Dividend represents a distribution of earnings to the shareholders of a company that are usually declared at Annual General Meetings and paid to shareholders of record. Dividend or profit allocation decision is one of the four decision areas in finance. The other three are financing, investment, and working capital management decisions. As noted by Ross, Westerfield and Jaffe (2002) companies view the dividend decision as quite important because it determines what funds flow to investors and what funds are retained by the firm for investment. Dividend policy can also provide information to stakeholders concerning the company's performance.

According to Foong, Zakaria and Tan (2007), the investments made by a firm determine the future earnings and future potential dividends; and dividend policy influences the cost of capital. In making these interrelated decisions, the goal is to maximize shareholder wealth.

Because banks are companies, their shareholders as rational investors usually expect to receive some income as return on their investments. The ability of a bank to pay dividends will depend to a large extent on its financial performance. Lasher (2000) was right when he noted that a decrease in dividend is taken as terrible news. It generally comes after a sustained reduction in earnings. There have been a number of studies on dividend policy especially in developed countries. Most of the studies examined dividend policy in general without focusing on a particular sector. Also, most of the literature on dividend policy use data from non-financial institutions, with very few on financial institutions.

In Ghana, studies on dividend policy have been limited to the determinants of dividend payout ratios of listed firms (Amidu and Abor, 2006), how does dividend policy affect performance of the firm on Ghana Stock Exchange? (Amidu, 2007), and dividend policy and share price volatility (Asamoah, 2010). Nonetheless, none of these researchers devoted his study wholly to banks. Ghana has witnessed the proliferation of banks over the past decade. As at the end of 2009 there were six banks listed on the Ghana Stock Exchange. In addition, there were seventeen (17) banks not listed on the Ghana Stock Exchange.

While some previous empirical studies show that dividend policy is irrelevant to firm value (Miller and Modigliani, 1961), others have proven otherwise (Gordon, 1961, 1962; Bhattacharya, 1979; and Allen and Michaely, 2002). This study seeks to provide further evidence on the impact of dividend policy on the performance of banks in a developing economy-Ghana. The study seeks to add to existing research in dividend policy for banks in a developing country. The rest of the paper is organised as follows: section two deals with a review of empirical 
studies and examines how dividend policy affects firm performance; section 3 discusses the methodology of the study; section four is on discussion of empirical results and; section five summarizes and concludes the entire study.

\section{Theoretical and Prior Studies}

Dividend policy of the firm is a complex but crucial issue in corporate finance. Although investors generally agree on some key determinants of dividend policy of firms, (for instance risk, profitability collateral capacity, ownership structure, cashflow, and taxation) the effect of dividend policy on firm value is largely contended. There has been a number of studies in the relevance or irrelevance of dividend decisions.

Miller and Modighani (1961) were the first to demonstrate that under certain assumptions (perfect market conditions, rational behavior and perfect certainty), the value of the firm is independent of the way the firm chooses to finance its investments and that all that matters is the firm's investment opportunities. This position has been largely criticized (see Allen and Michaely, 2002; Gordon, 1961, 1962; Bhattacharya, 1979; Shefrin and Statman, 1984; Lease et al, 2000; Amidu and Abor, 2006). They argue that important market imperfections such as asymmetric information, agency cost, taxes, transaction costs, floatation expenses and behavioural factors exist, in reality, and should be taken into consideration when assessing whether dividends have any impact on firm value. Consequently, when the assumptions of perfect market are relaxed, dividend policy is seen as relevant.

Kale and Noe (1990) suggest that dividend acts as a signal of the stability of the firm's future cashflows. A survey of the extant literature reveal that the key determinants of dividend decisions include liquidity, after tax earnings of the firm, cash flow considerations, future earnings, past dividend practices, returns on investment, legal requirements, growth prospects, inflation and interest rates. Brigham (1995) submit that dividends provide perhaps the best and most reliable signal. According to him, an increase in dividend signals management's confidence that future earnings will be strong enough to support new and higher dividend and vice versa. This view is corroborated by Foong, et al (2007) when they noted that there is evidence to support the view that investors respond to dividend changes. For example, Fama and Babiak (1968) found a time series relation been annual dividends and earnings that is consistent with the view that dividend paying firms increase their dividend only when management is relatively confident that their higher payments can be maintained.

Lintner (1956) found that the most important determinants of the size of company's dividend is a change in the firm's earning. Pruitt and Gutman (1991) found that the following factors are important influences in the amount of dividends paid, current and past years' profits, the year to year variability of earnings, the growth of earnings and prior years' dividends. More recently Capstaff, Klaeboe and Marshall (2004) also found that stock market reaction is more pronounced for large, positive dividend announcements that are followed by permanent cash flow increases. Foong, et al (2007) observed that although firms do not have obligations to declare dividends on common stock, they are normally reluctant to change their dividend rate policy every year as the firms strive to meet stockholders' expectation, build a good image among investors and to signal that the firm has stable earnings to the public. Also, Bhattacharya (1979) provide explanation for the positive stock price reaction to the announcement of dividend increases or initiation. In effect, they suggest that dividends have informational content which can be used to predict future earnings and prices. Also, using coefficient of correlation method, Few et al (2007) revealed that dividend-paying companies are relatively more profitable, less risky, matured and stable as compared to non-dividend-paying companies.

Consequently, the directional effect of dividend policy on firm performance continues to be a puzzle. What makes the debate even far from being resolved is the fact that most of these studies have been concentrated on developed economies. Meanwhile, prior studies reveal that dividend policies differ based on the type of firm, market/economy and over time. Glen et al. (1995) found that dividend policies in emerging markets differed from those in developed markets. They reported that dividend payout ratios in developing countries were only about two thirds of that of developed countries. (See also Brook et al., 1998; and Ramcharran, 2001). Al-Malkawi (2007) observes that the examination of dividend policy in emerging market has, until recently being much limited. Yet the sort of firm and market characteristics that may influence dividend policy may be present in developing markets in an exaggerated function than in developed markets.

For instance, in Ghana, firms incur floatation cost when issuing new shares. Also, currently in Ghana, dividends are subjected to $8 \%$ tax while capital gains are taxed at the rate of 15\%. (see Internal Revenue, Act 2000 (Act 592)). Again Banks, by their very nature are informationally opaque. Consequently the banking industry in Ghana has a number of imperfections which would make their dividend policy have an effect of their value.

Dividend payments, in Ghana, are recommended by directors but they do so in compliance with provisions in section 71(1) of the Companies Code 1963 Act 179 which states inter alia that return or distribution of any of its assets to its shareholders unless: a) the company is able, after such payment, return or distribution, to pay its debts as 
the fall due; b)the amount or value of such payment, return or distribution does not exceed its income surplus immediately prior to the making of such payment, return or distribution.

Section 30(1) of Banking Act (2004) Act 673 adds that a bank shall not declare or pay dividend on its shares unless it has: a) Completely written off all its capitalized expenditure; b) made the required provisions for non-performing loans and other erosions in asset values; c) supplied the minimum capital adequacy ratio requirements; and d) completely written off all its accumulated operating losses from its normal operations.

Consequently, this study hopes to find out the effect of dividend payments by banks on the performance of banks in Ghana.

\section{Methodology}

The study used panel data constructed from the financial statements of 16 commercial banks in Ghana for a period of 5 years, from 1999-2003. These financial statements were obtained from the Banking Supervision department of Bank of Ghana. STATA was used for the data analysis. Based on the Hausman (1978) specification test, the fixed effects model was preferred to the random effect model.

\subsection{The Model}

The study is modeled as follows:

$\operatorname{ROEEBIT}_{i, t}=\alpha_{0}+\beta$ DIVPOUT $_{i, t}+\delta \operatorname{RISKEBIT}_{i, t}+\hat{A} S D A_{i, t}+\eta L D A_{i, t}+\varnothing \operatorname{LOGSALES}_{i, t}+\operatorname{DASTGRO}_{i, t}+\gamma A G E_{i, t}+$ $\theta A G E S Q R_{i, t}+\varepsilon_{i, t}$

Where;

the variables are defined in Table 1 together with the expected signs for the independent and control variables. The dependent variable in the equation is performance (ROEEBIT) while the independent variable is dividend policy (DIVPOUT). The study also controls for the effect of the following factors on bank performance; risk, capital structure, size of bank, age and non-linearity of age.

\section{Discussion of Empirical Results}

\subsection{Descriptive Statistics}

Information on descriptive statistics is provided in Table 2 below. The results show that the average return before interest and taxes to equity was about $93.4 \%$. Also, banks in Ghana pay about $24.65 \%$ of their net income as dividend to their shareholders. Bank risk, for the period under study, is measured at about $29.81 \%$. In support of earlier studies, most banks are highly levered. Leverage accounts for about $89.8 \%$ with short-term debt alone accounting for $80.35 \%$. Banks, over the study period, recorded an average log of sales of 6.77879 and an asset growth rate of $56.74 \%$. While age had a $\log$ of 1.0817 , the average log of age squared was 1.5195 .

\subsection{Variance Inflation Factor}

The variance inflator factor (VIF) analysis was conducted on the independent and control variables, in order to test for the presence of multicolinearity. The result, as shown in table 3, shows clearly that the presence of multicolinearity is minimal. The mean VIF value of 2.97 is much less than 10 (the rule of thumb).

\subsection{Discussion of Regression Results}

The regression results in Table 3 show that dividend payout has a positive relationship with firm performance and this is significant at $2 \%$. Banks that pay dividend increase their profitability. This means that as management pay out dividend, they tend to send out good signals about the bank's performance and therefore attracting more customers to deal with. Dividend payout policy could also force management to be more efficient in the utilization of scarce resources (residual income). Again, the depletion of the bank's financial resources by dividend payment could also cause some banks to increase their leverage level, which in itself is an agent for high performance. Lastly, when available resources of banks are reduced by the payment of dividend, it can also reduce agency cost between managers and owners thereby increasing their performance. This result is consistent with (Bhattacharya, 1979; Capstaff et al, 2004; Amidu, 2007; and Few et al) but does not sit well with (Miller and Modigliani, 1961).

Risk increases the performance of banks in Ghana. This could be as a result of the fact that banks that enter into high risk ventures are able to attract premium interest that boosts their returns. Consistent with other previous study by Agyei (2010), high bank debt is associated with high bank performance. Although the size of a bank was found to be positively related to bank performance, the results were not significant. Nonetheless, growth in bank assets does not only influence bank performance positively but also significantly. It appears strongly that as banks grow their asset base, they are able to use the resources to generate more economic benefits. Also, Banks which have been in 
existence for some time appear to perform better than banks which are relatively new. This notwithstanding, at some point, matured banks begin to experience significantly negative effects on their performance.

\section{Conclusion and Recommendation}

The main thrust of this study was to find out the relationship between dividend policy and performance of banks in Ghana. From the results of the study, the average dividend paid by banks over the study period was $24.65 \%$. Also, it is apparent that firms that pay dividend increase their performance. Consequently, in Ghana, banks should pay dividends in order to reduce agency cost and enhance their performance. The results also reinforce earlier findings that leverage, size of a bank and bank growth enhance the performance of banks. The age factor presents mixed results. Although the length of time that a bank has been in existence could favourably influence bank performance, it is also clear that beyond a certain point age could influence bank performance negatively.

Consequently, our results suggest strong evidence in favour of dividend policy increasing the performance of banks. In other words, banks that pay dividend enhance their performance relative to banks that do not. Additionally, judicious debt use and strategies to increase firm size, bank growth, and appropriate level of risk taking, could also maximize bank performance.

Following from this study, future studies can look at the effect of dividend policy on the performance of other financial institutions like insurance companies.

\section{References}

Agyei, S. K. (2010). Capital Structure and Bank Performance in Ghana, Unpublished MPhil. Thesis, Graduate School, University of Ghana.

Allen F. and Michaely, R. (2002). Payout policy, Center for Financial Institutions Working Papers, 01-21.

Bhattacharya, S. (1979). Imperfect Information, Dividend Policy, and 'The Bird In the Hand. Fallacy', Bell Journal of Economics, 10(1), 259-270. doi:10.2307/3003330, http://dx.doi.org/10.2307/3003330

Al-Malkawi, N. H. (2007). Determinants of Corporate Dividend Policy in Jordan: An application of the Tobit Model, Journal of Economic \& Administrative Sciences Vol. 23, No. 2, 44-70.

Amidu, M. and Abor, J. (2006). Determinants of the Dividend payout ratio in Ghana, The Journal of Risk Finance Vol. 7, No. 2, 136-145. doi:10.1108/15265940610648580, http://dx.doi.org/10.1108/15265940610648580

Amidu, M. (2007). How does Dividend Policy affect Performance of the firm on Ghana Stock Exchange?, Investment Management and Financial Innovations, Vol. 4, Issue 2, 103-112.

Asamoah, G. N. (2010), Dividend Policy and Stock Price volatility In Ghana, EABR \& ETLC Conference Proceedings, Dublin, Ireland.

Brigham, E. F. (1995). Fundamentals of Financial Management. Harcourt Brace College Publishers. Orlando, F1. 423-489.

Brook,Y., W. T. C. Jr., and Hendershott, R. J. (1998). Do firms Use Dividends to signal Future Cashflow Increases?, Financial Management 27(3), 46-57. doi:10.2307/3666274, http://dx.doi.org/10.2307/3666274

Capstaff, J., Klaeboe, A. and Marshall, A. P. (2004). Share Price Reaction to Dividend Announcements: Empirical Evidence on the Signaling Model from the Oslo Stock Exchange, Multinational Finance Journal, 8(1/2), 115-139.

Fama, E. and Babiak, H. (1968). Dividend Policy: an Empirical analysis, American Statistical Association Journal, Vol.63, 1132-1161. doi:10.2307/2285874, http://dx.doi.org/10.2307/2285874

Few, S. L., Abdull, M., Mohd, L., Shahrin, A. R. and Othman, M. S. (2007). Dividend Policy: Evidence from Public Listed Companies in Malaysia, In: The 7th International Business Research Conference, December 3-6, 2007, Sydney, Australia.

Foong, S. S., Zakaria, N. B. and Tan, H. B. (2007). Firm Performance and Dividend-Related Factors: The Case of Malaysia, Labuan Bulletin of International Business \& Finance. Vol. 5, 97-111.

Glen, J.D., Karmokolias, Y., Miller, R. R. and Shah, S. (1995). Dividend Policy and behavior in emerging markets, International Financial Corporation, Discussion Paper No. 26.

Gordon, M. (1961). The Investment, Financing, and Valuation of the Corporation, Review of Economics and Statistics.

Gordon, M. (1962). The savings, investment and valuation of a corporation, Review of Economics and Statistics, 37-51. doi:10.2307/1926621, http://dx.doi.org/10.2307/1926621 
Hausman, J., (1978). Specification tests in econometrics, Vol. 46, 1251-71.

Internal Revenue Act, 2000 Act (592), Ghana.

Kale, J. R. and Thomas, H. N. (1990). Dividends, uncertainty and underwriting costs under asymmetric information, The Journal of Financial Research 13, 265-277.

Lasher, W. (2000). Practical Financial Management, (2nd ed.) Thomson South-Western.

Lease, K. J., Kalay, A., Loewenstein, U. and Sarig, O. H. (2000). Dividend Policy: It impact on firm value, Harvard Business School Press, Boston.

Lintner, J. (1956). Distribution of incomes of Corporations among Dividends, Retained Earnings, and Taxes, America Economic Review, 46, 97-113.

Miller, M. H., and Modigliani, F. (1961). Dividend Policy, Growth, and the Valuation of Shares, Journal of Business 34, 411-433. doi:10.1086/294442, http://dx.doi.org/10.1086/29444

Pruitt, S.W. and Gitman, L.W. (1991). The interactions between the investment, financing, and dividend decisions of major US firms, Financial Review, Vol. 26 No.33, 409-30. doi:10.1111/j.1540-6288.1991.tb00388.x, http://dx.doi.org/10.1111/j.1540-6288.1991.tb00388.x

Ramcharran H. (2001). An Empirical Model of Dividend Policy in Emerging Equity Markets, Emerg. Mark. Q. (5):4.

Ross, S. A., Westerfield, R. W. and Jaffe, J. (2002). Corporate Finance ( $6^{\text {th }}$ ed.), McGraw-Hill Companies.

Shefrin, H. and Statman, M. (1984). Explaining investor preference for cash dividends, Journal of Financial Economics, June, 253-282. doi:10.1016/0304-405X(84)90025-4, http://dx.doi.org/10.1016/0304-405X(84)90025-4

StataCorp. (2009). Stata Statistical Software: Release 11.0, Stata Corporation, College Station, Texas.

The Banking Act, 2004 Act (673), Ghana.

The Ghana Companies Code 1963 Act 179.

Table 1. Definition of Variables and their Expected Signs

\begin{tabular}{|c|c|c|}
\hline VARIABLE & DEFINITION & $\begin{array}{l}\text { EXPECTED } \\
\text { SIGN } \\
\end{array}$ \\
\hline $\operatorname{ROEEBIT}_{i, t}$ & $\begin{array}{l}\text { Dependent Variable: Bank Performance }=\text { the ratio of Earnings before interest and taxes to Equity } \\
\text { fund for bank } i \text { in time } t .\end{array}$ & \\
\hline$D_{I V P O U T}$ & $\begin{array}{l}\text { Independent Variable: Dividend Policy }=\text { the ratio of cash dividend paid to Net income for bank } i \\
\text { in time } t \text {. }\end{array}$ & Positive \\
\hline RISKEBIT $_{i, t}$ & $\begin{array}{l}\text { Control Variable: Bank Risk }=\text { the standard deviation of ROEEBIT for Bank } i \text { in time } t \text { from the } \\
\text { average ROEEBIT of bank } i \text { over the period. }\end{array}$ & Positive \\
\hline$S D A_{i, t}$ & $\begin{array}{l}\text { Control Variable: Bank Capital Structure }=\text { the ratio short term debt to net total assets for bank } i \text { in } \\
\text { time } t \text {.. }\end{array}$ & Positive \\
\hline$L D A_{i, t}$ & $\begin{array}{l}\text { Control Variable: Bank Capital Structure }=\text { the ratio of long-term debt to net total assets for bank } i \\
\text { in time } t \text {. }\end{array}$ & Positive \\
\hline$L_{O G S A L E S}$ & Control Variable: Bank Size $=$ the $\log$ of sales for bank $i$ in time $t$. & Positive \\
\hline$A S T G R O_{i, t}$ & Control Variable: Bank Growth $=$ the growth in net total assets of banks for bank $i$ in time $t$. & Positive \\
\hline$A G E_{i, t}$ & Control Variable: Bank Age $=$ the log of bank age for bank $i$ in time $t$. & Positive/negative \\
\hline$A G E S Q R_{i, t}$ & Control Variable: Non linearity of Age $=$ the square of $\log$ of age for bank $i$ in time $t$. & Negative/positive \\
\hline$\varepsilon_{i, t}$ & The error term & \\
\hline
\end{tabular}


Table 2. Descriptive Statistics

\begin{tabular}{|l|l|l|l|l|l|}
\hline VARIABLE & OBSERVATIONS & MEAN & STD. DEV. & MIN. & MAXIMUM \\
\hline ROEEBIT & 82 & 0.9335941 & 0.7208461 & -1.518046 & 3.032079 \\
\hline DIVPOUT & 82 & 0.2465337 & 0.2288715 & 0 & 0.7326623 \\
\hline RISKEBIT & 82 & 0.2981009 & 0.3416558 & 0 & 1.755602 \\
\hline SDA & 82 & 0.8034516 & 0.1283667 & 0.2574284 & 1.12622 \\
\hline LDA & 63 & 0.0952813 & 0.1041772 & 0.0014035 & 0.5691171 \\
\hline LOGSALES & 81 & 6.77879 & 0.6204086 & 4.717924 & 7.878944 \\
\hline ASTGRO & 64 & 0.5674432 & 0.5493302 & -0.274523 & 3.73925 \\
\hline AGE & 1.081705 & 0.5948771 & 0 & 2.2029384 \\
\hline AGESQR & 80 & 1.519541 & 1.332539 & 0 & 4.118398 \\
\hline
\end{tabular}

Table 3. Regression results for the model (dependent variable: ROEEBIT)

\begin{tabular}{|l|l|l|l|l|l|}
\hline Explanatory Var. & Coefficient & t- Stat. & Probability & VIF & $1 /$ VIF \\
\hline DIVPOUT & 1.0396 & 2.48 & 0.017 & 1.94 & 0.51499 \\
\hline RISKEBIT & 0.5912 & 2.13 & 0.039 & 1.50 & 0.66611 \\
\hline SDA & 4.8150 & 3.42 & 0.001 & 4.50 & 0.22204 \\
\hline LDA & 4.0420 & 2.01 & 0.052 & 4.85 & 0.20633 \\
\hline LOGSALES & 0.3471 & 1.20 & 0.237 & 3.71 & 0.26942 \\
\hline ASTGRO & 0.9361 & 3.89 & 0.000 & 1.68 & 0.59623 \\
\hline AGE & 2.1695 & 3.33 & 0.002 & 2.64 & 0.37914 \\
\hline AGESQR & -0.8970 & -2.95 & 0.005 & & \\
\hline CONSTANT & -7.4675 & -3.34 & 0.002 & & \\
\hline & & & & & \\
\hline R-sq: Overall & & & & & \\
\hline F-Statistic & & & & & \\
\hline Prob. (F- Statistic) $=0.0000$ & & & & & \\
\hline Haus. Test chi2(8) =95.53 & & & & & \\
\hline
\end{tabular}

